\title{
Toward a contemporary understanding of youth ministry as a descriptive agency
}

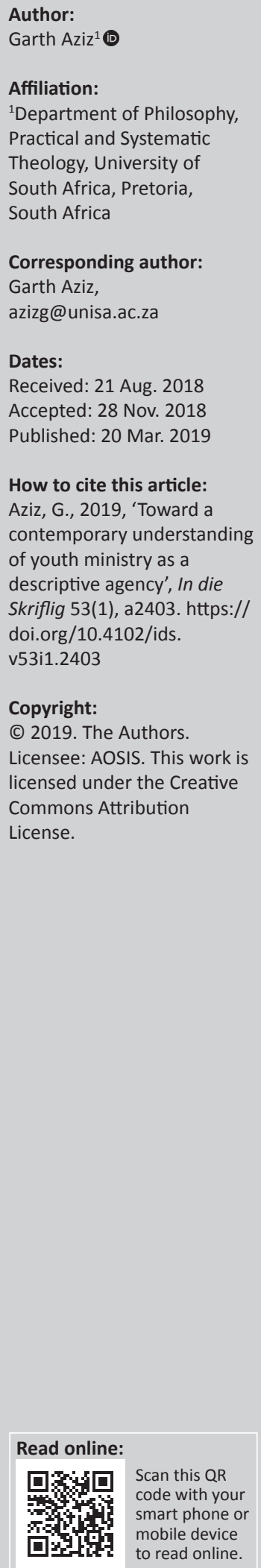

\begin{abstract}
Youth ministry within an evangelical protestant epistemology has predominantly been evangelistic, with the aim of reaching and proselytising unchurched youth and youth who do not have a personal and confessed relationship with Jesus Christ. Youth ministry, however, since its inception until the contemporary context of the 21st century, has gone through many challenges and transformations. The historical challenges of the youth ministry have birthed many developments to address the ever-increasing need of the adolescent world both globally and within South Africa. Youth ministry can no longer only be interested in the spiritual condition of the youth; instead, youth ministry should be an agency in the lived realities and experiences of the youth. The aim of the article is to argue that the efficacy of youth ministry in a contemporary society depends on its function as a descriptive agency that is informed by its mission, which is primarily ministry.
\end{abstract}

\section{Introduction}

The purpose of youth ministry can be manifold. Youth ministry can be 'instrumental in the building up of the local church' (Nel 2000:63). Youth ministry should also be intentional in assisting the youth ${ }^{1}$ to enjoy meaningful relationships with significant adults and peers (Black 1991:82-84). Furthermore, youth ministry should be 'offering a focused response of reconciliation' to the existential questions about life sought by adolescents as they struggle through life by creating safe spaces, by interpreting and reflecting on God's actions in their lives amidst their personal conflicts (Jacober 2011:22). In this sense, youth ministry serves as a 'mediation of the coming of God' (Nel 2003a:75) for the youth to have a meaningful relationship with God (Aziz 2014:13). For any denomination and local church to not only survive but to also flourish, its intentional focus on its ministry to the youth is paramount (Nel 2000:63). The church must be intentional about the ministry of its youth, which ultimately depends upon the theological departure points of the local church (Lomax 1997:22; Nel 2000:63). Youth ministries, however, have historically been prescriptive when engaging with the youth and their associated culture. This is often done by regurgitating age-old concepts and models instead of being observers of youth culture - especially as society becomes ever-increasing secular and pluralistic. For youth ministries to be effective despite its evolution and growth, the ministry should not be prescriptive but descriptive of the culture in which they are located. While acknowledging Keller's argument (2012:89) that the gospel of Jesus Christ and the biblical message does not change, the message should be given in a 'language and form' that can be understood. The gospel message should never be forced or coerced without engaging the context of the young person.

The evangelical expression of youth ministry continues to be dominated by a model of reaching the youth through evangelism so that they may have a confessed and personal relationship with Jesus Christ (Kageler 2004:76). This model of doing youth ministry often happens devoid of a contextual understanding and analysis of the lived realities and experiences of the youth. It often leads to the rehashing of concepts and theory that has little reflection on youth ministry praxis. It is governed almost blindly by focusing on the Bebbington quadrilateral (1989:3), namely conversionism, the belief that lives need to be changed; activism, the sharing of the gospel through human effort; biblicism, an authoritative and normative regard for the Bible; and crucicentrism, the centrality of the sacrifice of Christ on the cross.

This article will argue that for youth ministry to be meaningful to the youth, it should be a descriptive youth ministry. It is a youth ministry that is observant of youth culture and the lived

1.When utilising the term youth, it is inclusive of children, youth and young adults. It is also in line with the recommendations supplied by the National Youth Policy of South Africa (2015-2020) that extends youth to 35 years old. However, due to the focus of the article, it will be restricted to youth between 15 and 35 years old. The terms youth, adolescent, and young person will be used interchangeably in the article. 
realities and experiences of the youth. It remains an important endeavour for youth ministry as a subdiscipline of practical theology (Clarke 2008:10; Dean 2001:19; Jacober 2011:16; Nel 2003a:73; Strong 2014a) to be conversant with and knowledgeable about the youth culture and lived realities of the youth. Youth culture is an important part of the lived realities of the youth as it serves as a reflection of the world of the youth, but also as an indication of development and direction in the world of the youth. Mueller (2006:127) sees youth culture as a map and a mirror recognising that while culture shapes the youth, the youth in turn shapes culture too (Weber 2015:5). To understand not only the world of the youth but the youth themselves, it is important that youth ministry is therefore observant of important factors such as youth culture and the lived realities of the youth. Dames (2014:145) reflects on the difficult circumstances that the youth face and they also make decisions that are both moral and responsible without the necessary skills set. Furthermore, it is essential that for youth ministry to be meaningful as a descriptive youth ministry, it must be staffed with dedicated personnel who are skilled in some form of empirical reflection in the lives of the youth to whom they minister. This article is placed squarely in the epistemology of evangelicalism.

\section{The complexity of the adolescent world}

It does not require much for one to understand the complexities around the identity formation of adolescence, which can be described as a period of confusion, conflict and transition in the pursuit of individuation ( $\mathrm{Nel} \mathrm{2000:30;}$ 2003b:161). The South African context further complicates the journey for young people (Dames 2013:5ff.; Dreyer 1998:15; 2009:11). Young people are barraged with systemic violence that they have inherited from a troubled historic past of apartheid. A majority part of the youth has no or limited access to socioeconomic resources and a pervasive and debilitating poverty that has increased to $55.5 \%$ in 2015 with the most affected and vulnerable being the youth (Stats SA 2017). Youth unemployment during the first quarter in 2018 in South Africa was a staggering $38.2 \%$, which amounts to approximately 3.3 million young people (Stats SA 2018). Furthermore, the changing dynamics around the family concept, chemical substance abuse, and extreme cases of violence are just some examples of the contextual realities of a large part of the South African youth population (Amoateng \& Richter 2003; Baleka 2011:87; Holborn \& Eddy 2011; Kalule-Sabiti et al. 2007). While one cannot speak of a homogenous youth experience (Nel 2000:28), these are some general shared experiences among the South African youth. It is therefore safe to say that the world of the young person is complex and cannot be addressed through quick responses with simplistic answers. It is against this complicated background that youth ministry must minister to young people. This requires a critical understanding and response to the ministry of youth ministry.

\section{Ministry as the mission of youth ministry}

Youth ministry can be argued to be both ontological and functional. As an ontological ministry, it finds its existence in the person of God. Root (2009:59; 2014:93) uses the concept that God is a God of ministry and all ministries find their being in God. Ministry, according to Root (2016:59), is God revealing himself to people. As a functional ministry, youth ministry finds its praxis within the needs and context of the lived realities and experiences of individual young people and the society. Root (2016:60), however, cautions against a simplistic use of functional as merely stuff that God is doing. Functional, instead, should be considered as the act of God revealing himself to humanity and thus calling people, including the youth, to himself. God is interested in calling young people to himself. Nel (2000:79-80) uses the phrase 'God coming to his people', which he sees as a theological task of youth ministry. A youth ministry that fails to reflect upon its ministerial praxis will be deficient and weak, and will fail to realise that its ministry to the youth is its primary mission. A youth ministry that fails to possess a reflective characteristic is an example of a prescriptive youth ministry. The dilemma with a prescriptive youth ministry ${ }^{2}$ is that it can fall short of understanding its context - the lived experiences of adolescents - for meaningful ministry. The adolescent world has become a tumultuous sea of crisis. In South Africa, the foremost needs among adolescents are that youth ministry should take cognisance of the changing dynamics of the concept of the family, high unemployment, violent crime, risky sexual behaviour (Holborn \& Eddy 2011:3-15), chemical substance abuse, free access to quality education, and a general sense of purposelessness. For the youth ministry to embrace solely a prescriptive model for spiritual regeneration at the expense of adequate reflection on the lived realities and experiences of the youth is myopic and dangerous at the least.

Senter III et al. (2001:126) explain that the focus on the youth gained impetus during the Industrial Revolution, although Kirgiss (2015) argues that the concept of youth has existed as far back as the Middle Ages. Youth ministry can be traced and has its existence in its current form only within the last century. The Industrial Revolution not only raised the awareness of the human and civil rights of young people, but also on the developmental journey on which young people embarked. The Industrial Revolution thus caused the need to create agencies that focused on addressing these new and varied processes of young people. Youth ministry in the church was one of these agencies that has a functional history and has seen its growth and evolution accordingly with the growth of development of the youth and youth culture in the society. There was a need in society to reach the youth, and the church sought to meet that need. Ontologically, one can argue that the ministry to the youth is a theological reality that is captured throughout Scripture 2.The concept of a prescriptive and descriptive youth ministry will also be dealt in the article. 
and is explicitly affirmed by Jesus Christ's response to children (Nel 2000:9-15).

Youth ministry in any context should be elucidated through both its functional and ontological nature. As previously stated, youth ministry in Protestant churches has usually been focused on leading the youth to salvation with the aim of being progressed through discipleship into becoming part of the church and its culture. ${ }^{3}$ As already indicated, while the objective of youth ministry depends on the theological departure points of the local church, this article argues that it is to help facilitate young people to experience a deep and meaningful relationship with God.

Unfortunately, evangelical youth ministry has often been segmented into either evangelism or discipleship and yet, it is more than just those two aspects (Dean 2011:19-21). Contemporary youth ministry, however, should recognise a more holistic approach to and with the youth as well as their role as active agents in their contribution to society. It is therefore important to clarify the objective of the contemporary youth ministry as one that seeks to understand God's action with and through the youth. Therefore, youth ministry correctly should be contextual (Dean 2011:20); however, it cannot have a mandate different to that of the local church, and its context as youth ministry is part of the comprehensive ministry of the church (Nel 2001:21-22).

In line with the above, the focus of youth ministry should be the following: (1) the youth as objects of God's grace; (2) the youth as missional agents; and (3) the youth informing praxis.

\section{Youth as objects of God's grace}

As a legitimate theological discipline (Nel 2003a:75; 2005:18), youth ministry has its purpose of assisting adolescents into a deeper relationship with God; to be connected to God through Jesus Christ (Strong 2015:4). However, Strong (2014b:9) maintains that youth ministry has not always been successful in assisting the youth to experience a lasting and mature relationship with God. Strong (2014a:2; 2015:4) argues that it is God's desire for 'every adolescent and child, to be saved and to be in a personal relationship with Him'. This is entirely a theological task whereby the youth may participate in God's story that is active in their lives (Root 2012:38). The focus of the youth being the objects of God's grace is not on processes or outcomes, but on the journey with God whereby God reveals himself to the youth (Nel 2003a:77-79; Root \& Dean 2011). Strong (2015:4) argues that this relationship with God cannot be taught, 'it is only something that can be caught'. This revelation of God often results in an acceptance of meaning amidst their circumstances (Aziz 2014:237). Furthermore, this meaning should be realised where the youth are able to 'seek the truth and discover who they are in Jesus Christ' (Strong 2015:4). The youth matters to God; it

3.See Senter et al. (2001). In this work, the various authors argue different approaches to youth ministry, yet almost unanimously. They argue that eventually the youth
ministry should be geared toward integrating the youth into the life and culture of ministry shoulc
the church. therefore becomes the primary task for youth ministry to assist the youth to experience this deep and meaningful relationship with him.

\section{Youth as missional agents}

The actualisation of the divine-human relationship as well as experiencing significance and meaning to their lives should be facilitated through empirical research, theological reflection and understanding (Root 2007:10). Yet a caution exists, as argued by Root (2016), that the empirical has its limitations, because it cannot adequately explain or give meaning to the transcending nature of God. In other words, the empirical should never be the master of the theological (Root 2009:70; Swinton \& Mowat 2011:vii). Reflecting on the theological, however, should not be regarded as an escape from the empirical. Dean (2011:17-18) argues that youth ministry 'studies those moments, contexts, situations and practices in which God's action intersects with our actions, to transforms paltry human effort into something holy and lifegiving'. It is the role of youth ministry to understand, reflect, empower and assist in the transformation of the lives of young people so that they may experience this meaningful relationship with God. This specific role of youth ministry is defined by the Great Commission as discussed by Strong (2014b:2). An empirical understanding and reflection of adolescent practice requires a certain skill and knowledge that should be expected of every youth practitioner; these are a skill and knowledge that should be acquired. The challenge therefore is whether we have the resources for effectively dealing with the youth in our youth ministries in the context we find ourselves that we may either develop or refine theories of practice. It therefore becomes an important part of ministry to recognise the role that the youth themselves offer as missional agents in youth ministry. The youth are collaborators in youth ministry (Nel 2003a:73). Strong (2014b:6) states that there is a reciprocal relationship among the youth as they care for and help each other. This relationship, Strong (2014b:7) argues, is birthed in their passion. However, this passion has to be harnessed and channelled so that God is glorified through their actions. Strong $(2014 b)$ continues by stating that:

adolescents do not want to suffer, but they desperately want to love something (or someone) worthy of suffering - and to be so loved. They yearn for experiences that will channel their passions. (p. 7)

The youth therefore have a powerful opportunity to share the love of God amidst their circumstances and invite their peers to recognise that love and to pursue the saving grace of God for their lives.

\section{Youth informing praxis}

The theological approach in youth ministry, while not limited or restricted to an elitist and professional group of people, nonetheless lends itself to the need for trained and dedicated personnel with adequate theological training and ability to understand, reflect and interpret the information to inform 
praxis in the local church and society (cf. Clarke 2008:26; Nel 2003a:82). While volunteer staff is indispensable and should never be undermined, one should acknowledge the limitations of volunteer staff in a more complex society where the needs of the youth are to be considered holistically. It has been noted that from the office of the Presidency in South Africa (National Youth Development Agency 2013; The Commonwealth 2013; The Presidency of South Africa 2013; Unisa 2013), there is a need for a professional youth workers mandate. While the concept of the professional youth worker might not have been a focus in the theological sector, the theological sector remains integral in informing the development of the professional youth workers (NYDA 2008:7). It is vital that the church not only recognises the context of our youth but engages intentionally with the concept of career and vocational youth workers who are professional at the skills required (Nel 2003a:82). Nel (2005) argues:

that people in ministry (full or part-time) should be able to reflect upon the ministry with regard to knowledge, insight, competency and attitude as to what we do, why we do it, how we do it, and with what attitude we do it ... everyone working with the young and the vulnerable should have a fair amount of theological training. (p. 21)

Strong (2014b:5) too argues that there is a specific skill set, reflection and adaptation required by leaders in youth ministry. However, it does remain a greater challenge allowing unskilled youth ministers in youth ministry, without a concerted effort at appropriate training to participate in the lived experiences of the youth. This may may undermine the value and importance of the youth.

Youth ministry therefore should take seriously the context and culture of the youth in order that the youth may experience a deep and meaningful relationship with God. Youth ministry should also consider the youth as vital agents in the sharing of God's love, and that the youth ultimately informs the youth ministry praxis. Youth ministry should therefore have skilled youth ministers being active in this ministry to reflect and change praxis where and when required.

\section{Dealing with the prescriptive problem}

Youth ministry, as previously argued, should help to facilitate and empower young people in developing a deep and meaningful relationship with God. It is a mutual facilitation where the young person is an active participant and it is not a one-directional activity where the youth minister does all the work. Youth ministry is contextual; its ministry is to be contextual. It is therefore logical to argue that youth ministry no longer can be a prescriptive, pragmatic utilitarian, a 'what to do approach' (Root 2007:10). A pragmatic utilitarianism will always fall short of responsible theological reflection, especially in a context like postapartheid South Africa where the need of the youth is ever pressing (Aziz 2014:4; Holborn \& Eddy 2011:3-15). The very nature of youth ministries lends itself to being descriptive. A youth ministry is always hermeneutical. Its ministry should be seeking to discern where God is busy and where God is busy revealing himself, not merely in the church or community, but in each individual young person's life (Root 2014:99). Youth ministry as a theological discipline is to discern God's activity (ontological) with and among young people. Its ministry therefore is to consider the context of the lives and experiences of young people to fulfil its purpose. The ministry of youth ministry should ask: 'Where is God working?' and 'What is He doing?' The ministry of youth ministry is also contextual (functional), discerning, reflecting, interpreting and transforming the lives and contexts of individual youths and communities. The very existence (ontologically) of youth ministry is to serve as a hermeneutic where God reveals himself to enact its contextual (functionally) ministry in the lives of young people so that they may have an encounter with him and make sense of their existence and experience (Müller 2004:96).

It is understandable then that Browning (1991) argues that the descriptive task of theology is:

to describe the contemporary theory-laden practices that gives rise to the practical questions that generate all theological reflection. To some extent the first movement is horizon analysis; it attempts to analyse the horizon of cultural and religious meanings that surround our religious and secular community. (p. 47)

Browning (1991) continues by stating that:

The main task of descriptive theology, however, is to form questions that are brought back to the classics for the creation of new horizons of meaning. These horizons of meaning are the most basic, most threatening, and finally most truly powerful sources of transformation. These new horizons transform our fundamental visions and narratives that provide the envelope for practical reasoning. (p. 285)

Similarly, Osmer $(2008: 33,38)$ attempts to discover what is going on within any community and context - the lived and concrete realities of people. What people do is laden with theory, as no practice exists without being informed by theory. Osmer (2008:32) argues that we have to reflect and interpret the lives of those to whom we minister to as 'living human documents'. His focus here is 'priestly listening' by enquiring 'What is going on?' The answer to this question, for Osmer (2008:38), is achieved through empirical research. This descriptive theology is realised through empirical research, understanding, interpretation, and reflection of events and experiences of 'ordinary people in everyday life' (Osmer 2008:24). It is more than just the interpretation or application of the normative texts of the religious community (Osmer 2008:24), which often results in a prescriptive theology.

A descriptive youth ministry should begin with youth ministers immersing themselves in the context of young people and listening 'to the stories of need' (Meylahn 2003:158) to identify the questions of need. It is only once we know what the questions of need are, that we can 'unpack the 
story' (Meyhlann 2003:158). Unpacking the story, for Meylahn (2003:158), is an attempt to listen while unpacking these stories of need; a process where the participants are considered as co-researchers in the unpacking of their stories. A positive aspect of this approach is the consideration and acknowledgment of the youth as co-researchers. The process, however, remains one that is subjective where the co-researchers are the ones who interpret their own stories, which could lead to a distorted interpretation and a 'radical subjectivity' (Dreyer 2014:7). Dreyer (2014:7), however, cautions against this approach, as there is a 'reluctance' of serious empirical and scientific research. It is in line with this caution that there is a further need and justification for the skilled youth minister.

Root (2014:87-115) argues that the descriptive approach should be ontological more than it is epistemological. He argues that revelation and reconciliation are found in the praxis of Christ (ontology) and not in the logic and systems of human knowledge (epistemology), which often comprises of an interdisciplinary discussion. His argument is that ministry (ontology) precedes theology (epistemology) - it is out of ministry (the mission of Christ) that the praxis of Christ (the cross of Christ) is experienced. Christopraxis for Root, as research methodology should take cognisant of the revelation of Christ - God coming to humanity - and not merely thick descriptions enforced by an epistemology of interdisciplinary praxis - humanity knowing God.

As an Evangelical, a descriptive youth ministry should take the ministry of Jesus Christ, the lives and experiences of young people, and an interdisciplinary engagement through the empirical seriously. A descriptive youth ministry therefore requires the youth worker to listen, investigate, reflect and interpret the everyday stories, experiences and lives of adolescents. This should be done to define or refine what the ministry of the youth ministry should be, as the youth continually experience Christ in various ways and moments. A descriptive youth ministry is the ministerial act whereby God reveals himself to humanity and simultaneously drawing people unto him. Youth ministry is not to morph or develop into some culturally relevant agency for it to be more relevant to youth culture. Instead, it should interpret the lives and culture of the youth through the ministry of Christ on the cross - to fulfil its mission and so that the youth may experience a deepening relationship with God - which is the purpose of youth ministry within an evangelical community.

\section{A way forward in youth ministry as a descriptive agency}

Without being too simplistic, at this point I want to submit two possible suggestions on the way forward in youth ministry as a descriptive agency in an evangelical context. These suggestions are: (1) the primary task of youth ministry is hermeneutical. Therefore, youth ministry ought to serve as a hermeneutical agency in the lives of the youth; and (2) due to youth ministry serving as a hermeneutical agency, its praxis should be informed by being empirical.

\section{Youth ministry as a hermeneutical agency (ontological)}

The ministry of youth ministry is multifaceted, and as mentioned before, is ultimately to help facilitate young people into a meaningful relationship with God. Yet, evangelism and discipleship, as characteristics of evangelical youth ministries, without reflection on the lived realities and experiences of the youth, should never be the sole aim of youth ministry. Youth ministry should serve as a hermeneutical agency to help the youth discern God's working in their lives and reflect on their lives what God's plans could be for them (Aziz 2014:13; Nel 2003a:75). The ministry of youth ministry should always be contextual by reflecting on the needs and context of each young person. At no time would any two youth ministries be alike in their ministry to, with, and through young people. The question that needs to be answered is, how does a youth ministry serve as a hermeneutical agency? Youth ministry is both corporate - by taking into consideration the community of both the church and the society, as well as individualistic - by seeking to impact the individual life of every young person it encounters. While God primarily approaches the youth through their primary care givers (Nel 2001:12), one should not ignore the church as a sphere where and through whom God too approaches the youth. Youth ministry should not exist in isolation of the church. Instead, it is the very corporate nature of the church that could foster the presence of God as he continues to engage with a community of people (see Nel 2001:2-22). Youth ministry as a hermeneutical agency, therefore should be both individual and corporate. While the following have not been addressed in the article, youth ministry could therefore consider the role of significant adults in the journey of the youth; by implication, be more intergenerational in the life of the church. Secondly, youth ministry could consider the significance of ritual as a means of contemplation in the revelation of God's action in the lives of the youth.

\section{Empirical research as ministry (functional)}

To have a more contextually relevant ministry for the youth, those involved in youth ministry should seek to know and understand the context of the young people. Youth ministry must be a continual conversation of the ministry of Jesus Christ (ontology), theological principles, concepts, and traditions (epistemology), the societal changes (culture), and the needs of young people (functional). To facilitate this conversation, youth ministers need to have a basic understanding of and be skilled as empirical researchers by reflecting and engaging continually with context (Nel 2003a:82). If the youth minister cannot engage and reflect on the context, a thorough understanding of the ministry of youth ministry will be shallow and quite possibly futile. 
There should be continual research in the lives and experiences of young people. Youth ministry, therefore, should be staffed with skilled personnel, utilising and refining trusted methodologies, or developing new methodologies that is applicable to youth ministry within a South African context (Nel 2003a:75-76). Nel (2003a:75-76) argues that there are many well-developed practice theories in youth ministry, ultimately these 'practice theories' are 'contextually determined as well as contextual in nature' and would require serious revision in a context such as South Africa. This would require life-long and informal training of the many volunteers in youth ministry who may not have the required skills for this type of empirical research in youth ministry. This research regarding the lived realities of South African youth should aim to build a greater publication record in order to build a more robust literary wealth on information in a South African context. While it is good to dialogue with international agencies and taking into cognisance the global community of the youth, we should recognise that our ministry is vastly different from that of our international colleagues and therefore require unique South African information. A caution at this point, while empirical research is paramount, the youth should never be regarded as an object to study to further our academic pursuits. Instead, they should be the focus of our study so that they may enjoy the divine-human relationship.

\section{Conclusion}

In this article, I have argued that the ministry of youth ministry within an evangelical context is to help facilitate the youth into a deep and meaningful relationship with God. Understandably, there cannot be a single and unified ministry in youth ministry, as each youth ministry will differ according to each context where a local church finds itself, as well as the lived reality and experiences of each young person. The ministry of youth ministry should be contextual. Youth ministry should be descriptive, as a one-for-all prescriptive mandate will fail to be effective, as it often does not take cognisance of the contexts of the communities and the specific lived realities and experiences of each youth. While there may be various means and definitions of being descriptive and it cannot be exhausted, it remains fundamental to understand that the ministry of youth ministry is based on the very existence of God and the ministry of Jesus Christ as both an ontological and functional reality. Furthermore, it should be a requisite that the youth minister should at least have a basic knowledge and understanding of empirical enquiry to reflect more effectively on the lived reality and experiences of the youth in light of the ontological and functional nature of youth ministry.

\section{Acknowledgements Competing interests}

The author declares that he has no financial or personal relationship(s) which may have inappropriately influenced him in writing this article.

\section{References}

Amoateng, A.Y. \& Richter, L., 2003, 'The state of families in South Africa', in J. Daniel, A. Habib \& R. Southall (eds.), State of the nation: South Africa 2003-2004, pp. 242-268, HSRC Press, Cape Town.

Aziz, G., 2014, 'Youth ministry as an agent for reconciliation in the breakdown of coloured families, from urban communities in Cape Town: A post-apartheid perspective', The South African Baptist Journal of Theology 2, September, 231-241.

Baleka, B., 2011, 'African realities for youth ministry', in T. Linhardt \& D. Livermore (eds.), Global youth ministry: Reaching asdolescents around the world, pp. 87-95, Zondervan/Youth Specialties, Grand Rapids, Michigan.

Bebbington, D., 1989, Evangelism in modern Britain: A history from the 1730s to the 1980s, Unwin Hyman, London.

Black, W., 1991, Anintroduction to youth ministry, Broadman Press, Nashville, TN.

Browning, D., 1991, Afundamental practical theology: Descriptive and strategic proposals, Fortress Press, Minneapolis, MN.

Clarke, C., 2008, 'Youth ministry as practical theology', Journal of Youth Ministry 7(1), 9-38.

Commonwealth, 2013, South African President launches commonwealth youth worker conference, viewed 30 August 2013, from www.thecommonwealth.org/ne ws $/ 253897 / 200313$ youthworkerconference.htm

Dames, G.E., 2013, 'Knowing, believing, living in Africa: A practical theology perspective of the past, present and future', HTS Teologiese Studies/Theological Studies 69(1), Art. \#1260, 1-9. https://doi.org/10.4102/hts.v69i1.1260

Dames, G.E., 2014, A contextual transformative practical theology in South Africa, AcadSa Publisihing, Parow.

Dean, K.C., 2001, 'Theological rocks: First things first', in K.C. Dean, C. Clark \& D. Rahn (eds.), Starting right: Thinking theologically about youth ministry, pp. 15-23, Zondervan, Grand Rapids, MI.

Dean, K.C., 2011, 'Introduction', in A. Root \& K.C. Dean (eds.), The theological turn in youth ministry, pp. 13-24, IVP, Downers Grove, IL.

Dreyer, J.S., 1998, 'The researcher: Engaged participant or detached observer?', Journal of Empirical Research 11(2), 5-22, viewed 14 June 2016, from http://0booksandjournals.brillonline.com.oasis.unisa.ac.za/content/journals/10.1163/15 $7092598 \times 00103$

Dreyer, J.S., 2009, 'Establishing truth from participation and distanciation in empirical theology', in L.J. Francis, J. Astley \& K.C. Robbins (eds.), Empirical theology in texts and tables: Qualitative, quantitative and comparative perspectives, pp. 3-26, Brill, Leiden.

Dreyer, J.S., 2014, 'The narrative turn in practical theology: A discussion of Julian Müller's narrative approach', Verbum et Ecclesia 35(2), Art. \#889, 1-9. https://doi. org/10.4102/ve.v35i2.889

Holborn, L. \& Eddy, G., 2011, First steps to healing the South African family, viewed 26 March 2013, from http://www.sairr.org.za/services/publications/occasionalreports/files/first-steps-to-healing-the-south-african-family-final-reportmar-2011.pdf

Jacober, A.E., 2011, The adolescent journey: An interdisciplinary approach to practical youth ministry, IVP, Downers Grove, IL.

Kageler, L., 2004, 'A global youth pastor salary survey: Sociological and ecclesiological perspectives', Journal of Youth Ministry 2(2), 75-97.

Kalule-Sabiti, I., Palamuleni, M., Makiwane, M. \& Amoateng, A.Y., 2007, 'Family formation and dissolution patterns', in A.Y. Amoateng \& T.B. Heaton (eds.), Formation and dissolution patterns in families and households in post-apartheid South Africa: Socio demographic perspectives, pp. 89-112, HSRC Press, Cape Town.

Keller, T., 2012, Center church: Doing balanced, gospel-centred ministry in your city, Zondervan, Grand Rapids, MI.

Kirgiss, C., 2015, In search of adolescence: A new look at an old idea, The Youth Cartel, San Diego IL.

Lomax, R., 1997, Youth ministry, Baptist Publications and Language Centre, Zeerlust, SA.

Meylahn, J.A., 2003, Towards a narrative theological orientation in a global village from a postmodern urban South African, PhD thesis, Dept. of Theology, University of Pretoria.

Mueller, W., 2006, Engaging the soul of youth culture: Bridging teen worldviews and Christian truth, IVP, Downers Grove, IL.

Müller, J., 2004, 'HIV/AIDS, narrative practical theology, and postfoundationalism: The emergence of a new story', HTS Teologiese Studies/Theological Studies 60(1\&2), 293-306. https://doi.org/10.4102/hts.v60i1/2.516

National Youth Development Agency ACT (NYDA), No. 54, 2008, viewed n.d., from http://www.thepresidency.gov.za/docs/nyda_act.pdf

National Youth Development Agency, 2013, Fact sheet: Appendix 1.1, South Africa viewed 30 August 2013, from http://ccetyw.cyponline.org/NYDA\%20fact\%20 sheet.pdf

National Youth Policy, 2015-2020, viewed 18 August 2015, from http://www. thepresidency.gov.za/MediaLib/Downloads/Downloads/NYP\%20Policy\%20 2020\%20Report.pdf

Nel, M., 2000, Youth ministry: An inclusive congregational approach, Malan Nel, Pretoria.

Nel, M., 2001, 'The inclusive congregational approach to youth ministry', in M.H. Senter III (ed.), Four views of youth ministry and the church, pp. 1-22, Zondervan, Grand Rapids, MI.

Nel, M., 2003a, 'Youth ministry as practical theology: Making a case for youth ministry as an academic discipline', Journal of Youth and Theology 2(1), 68-83. https://doi. org/10.1163/24055093-90000205 
Nel, M., 2003b, 'Youth ministry: The challenge of individuation', Practical Theology in SA 18(1), 151-196.

Nel, M., 2005, 'Why theology? It's only youth ministry', Journal of Youth and Theology 4(1), 9-22. https://doi.org/10.1163/24055093-90000124

NYDA, see National Youth Development Agency.

Osmer, R.R., 2008, Practical theology: An introduction, Eerdmans, Grand Rapids, MI.

Presidency of South Africa, 2013, Welcome address delivered by the NYDA Chief Executive Officer (CEO) Steven Ngobeni on behalf of Minister in The Presidency for Performance and Monitoring and Evaluation, Collins Chabane at the Commonwealth Conference on Education and Training of Youth Workers, University of South Africa (UNISA), Pretoria, viewed 30 August 2013, from www. info.gov.za/speech/DynamicAction?pageid=461\&sid=35042\&tid=101918

Root, A., 2007, 'Youth ministry as discerning Christopraxis: A hermeneutical model', Journa of Youth and Theology 6(1), 9-31. https://doi.org/10.1163/24055093-90000224

Root, A., 2009, 'Practical theology: What is it and how does it work?', The Journal of Youth Ministry 7(2), Spring, 55-72.

Root, A., 2012, Taking theology to youth ministry, Zondervan, Grand Rapids, MI.

Root, A., 2014, Christopraxis: A practical theology of the cross, Fortress Press, Minneapolis, MN.

Root, A., 2016, 'Regulating the empirical in practical theology on critical realism, divine action, and the place of the ministerial', Journal of Youth and Theology 15(1), 44-64. https://doi.org/10.1163/24055093-01501007
Root, A. \& Dean, K.C., 2011, The theological turn in youth ministry, IVP, Downers Grove, IL. Senter, M.H. III, Black, W., Clark, C. \& Nel, M., 2001, Four views of youth ministry and the church, Zondervan, Grand Rapids, MI.

Stats SA, 2017, 'Poverty trends in South Africa: An examination of absolute poverty between 2006 and 2015', South Africa, viewed 18 August 2018, from http://www. statssa.gov.za/?p=10341

Stats SA, 2018, 'Youth unemployment still high in Q1:2018', viewed 18 August 2018 from http://www.statssa.gov.za/?p=11129

Strong, P., 2014a, 'Effective youth ministry: Embracing a family-orientated approach', In die Skriflig 48(1), Art. \#1715, 1-8. https://doi.org/10.4102/ids.v48i1.1715

Strong, P., 2014b, 'Christ alone ... redeeming youth ministry', In die Skriflig 48(1), Art. \#1716, 1-9. https://doi.org/10.4102/ids.v48i1.1716

Strong, P., 2015, 'Effective youth ministry: Theology-driven in a cultural context', In die Skriflig 49(1), Art. \#1889, 1-9. https://doi.org/10.4102/ids.v49i1.1889

Swinton, J. \& Mowat, H., 2011, Practical theology and qualitative research, SCM Press, Suffolk.

Unisa, 2013, First youth workers conference at Unisa, viewed 07 July 2013, from http://www.unisa.ac.za/cedu/news/index.php/2013/04/first-youth-workersconference-at-unisa/

Weber, S., 2015, 'A (South) African voice on youth ministry research: Powerful or powerless?', HTS Teologiese Studies/Theological Studies 71(2), Art. \#2973, 1-6. https://doi.org/10.4102/hts.v71i2.2973 